\title{
Stockbrokers' Services Availed by Equity Investors : A Study of Punjab, India
}

\author{
Effulgence \\ Vol. 16 No. 2 \\ July - December, 2018 \\ Rukmini Devi Institute of Advanced Studies \\ E-mail : effulgence@rdias.ac.in, Website : www.rdias.ac.in \\ http://effulgence.rdias.ac.in/user/default.aspx \\ https://dx.doi.org/10.33601/effulgence.rdias/v16/i2/2018/14-31
}

\section{Dr. Jaspreet Kaur ${ }^{1}$}

\begin{abstract}
Retail equity investors seek guidance from stockbrokers to manage their investment and to meet their own and their families' goals. These investors rely on stockbrokers for investment advice and expect that advice to be given in their best interest.. The study has been to analyse the various services availed by retail equity investors from the stockbrokers while dealing in securities market and to check whether there is any significant difference in the opinion equity investors across their demographics regarding the stockbrokers' services availed by them. Three hundred and seventy three (373) questionnaires have been filled up by the respondents. Forty five (45) questionnaires have been found to be incomplete and have been excluded from the analysis. Remaining three hundred and twenty eight questionnaires have been used for the analysis. In order to achieve the objective of the study descriptives, T-test and ANOVA have been used.
\end{abstract}

Keywords: Stockbrokers, investors, stockbrokers' services, securities market.

\section{INTRODUCTION}

$\mathrm{R}$ etail equity investors seek guidance from stockbrokers to manage their investment and to meet their own and their families' goals. These investors rely on stockbrokers for investment advice and expect that advice to be given in their best interest. The regulatory regime that governs the provision of investment advice to retail investors is essential to assuring the integrity of that advice and to matching legal obligations with the expectations and needs of investors (Study of the staff of the U.S. Securities and Exchange Commission, 2011). The customers have been empowered by the regulators and stock exchanges through numerous initiatives like the introduction to new investment avenues, educating and making the investor aware, increasing his reach, advancement of technology and higher accountability of various market participants. These steps will encourage the retail investors to invest in stock market. (Srinivasan and Mohan, 1995 and Chakravarty, 2010).

The Indian stock brokerage industry has grown significantly over the last decade in terms of both size and scope. The relationship between the

1. Assistant Professor, Khalsa College for Women, Amritsar, wassan.jaspreet@yahoo.com 
stockbroker and the investor has always been very rocky and also very beneficial to both of them. The broker has an inside knowledge about the companies and also the share market. So, he can always help the investor to make the right investment decision and thereby charge a fee for the services offered. The investor may be new to the market; therefore the knowledge accumulated by the stockbroker as per his experience can be greatly beneficial to the small investor who may be a first timer or a new entrant to the stock market. If the advice given to the first timer is beneficial to him, then there may be many more first timers who will be introduced to the stockbroker by the benefitted one (Rajkumar, K.Prabhakar and Kavitha, N. Lakshmi, 2015).

With gold prices fluctuating and the real estate not being up to the mark, the individuals have found a good and lucrative investment option which can be done with as low as Rs 1000/- per month, which is a very negligible amount in today's world (Volpe, Kotel, and Chen, 2002 and Vosra, and Younes, 2013). The stock market has seen a steady growth and most of the share prices have been constant with an increase in the same. Many small time investors are waiting to enter the stock market and test the waters. Since most of them will be first time investors, they will require knowledge about the market and also details of the companies which can be provided by the brokers, for a fee and if the small investor is given good advice then he/she may introduce many more clients to the broker who in turn may earn more, thereby making the situation a win- win one for the investor and also the broker.

\section{REVIEW OF LITERATURE}

McAlexander and Scammon (1988) concluded that high knowledgeable investors required problem specific advice and they used professional persons' recommendations and company report as a source of information. Moreover, they considered advisors' knowledge as the most important attribute while selecting the financial advisor. Hirst, Koonce and Simko (1995) stated that investors relied upon unfavourable report of IB analysts rather than on their favourable reports because their favourable reports were biased being based on incentives given to them by the companies, rather than on the basis of facts. The researchers opined that the situation must really be bad if IB analysts were willing to admit it. Chakrabarti (2004) highlighted that stock brokers recommendations were significantly helpful to investors especially the strong buy recommendations and these recommendations also had an impact on the prices of the relevant stocks. Chi (2006) highlighted that in the absence of brokers recommendations, investors were willing to sell the stock in both circumstances i.e. in case of loss as well as profit. When the impact of brokers recommendations were analysed, it was found that investors were following their recommendations. Hung, Clancy and Dominitz (2009) the study revealed that 1 . investors were not able to understand the key distinctions between investment advisors and brokers with regard to their duties, the titles used by them and the fees charged by them, 2 . investors were satisfied with their financial service providers. Verma and Tiwari (2010) suggested that the stock brokers should satisfy their existing customers in order to avoid revenue loss and to acquire new customers through the existing customers. Shukla and Upadhyaya (2013) revealed that customer satisfaction in broking agencies was highly influenced by attributes of services and the way in which these services had been delivered to the customers. The study recommended that the broking agencies need to invest more money and gain more expertise in their in house research activities. Jeelan (2014) found that1. number of registered stockbrokers increased gradually, 2. the number of registered stockbrokers of proprietorship was declining at snail pace from fifty percent to forty four percent, 3 . the registered brokers of corporatorship were increasing gradually from forty six point four percent $(46.4 \%)$ to fifty three percent (53\%), 4. major share in premier stock exchanges like BSE, NSE, OTCEI, Delhi, Ahmadabad were of corporatorship stock broking firms, 5. number of registered stockbroker in equity derivative segment 
were more than those of cash segment, 6. about twenty five percent $(25 \%)$ of the total turnover of cash segment was captured by top ten share brokers, 7. brokerage paid on trade had been steadily declining with CAGR of $-12.19 \%$ and 8 . brokerage paid on delivery had also been steadily declining with CAGR of $-5.9 \%$. Imthiyas, Shyamasundar and Ramar (2015) recommended to include the introductory sessions related to investment awareness in the academic curriculum so that root was soiled with proper fertilizers and investment professionals should be instrumental in spreading awareness among investors apart from profit booking. Rajkumar and Kavitha (2015) concluded that middle class people should be encouraged to invest in the stock market and stock brokers should also be encouraged to give the correct advice to the investors so that they could get many more people to the stock market.

\section{HYPOTHESIS DEVELOPMENT AND DATA COLLECTION}

By personally visiting the offices of the stockbrokers, one thousand questionnaires have been distributed among retail equity investors of Punjab i.e. Amritsar, Jalandhar, Ludhiana and Mohali. Stockbrokers have been selected by using simple random sampling technique due to their large number. Questionnaires have been got filled by 1 . personally visiting the stock brokers' offices and handing over the questionnaires to the stock brokers and asking them to get these filled from their clients, 2. sitting in the offices of the stock brokers and personally asking their clients to fill the questionnaires. Three hundred and seventy three (373) questionnaires have been filled up by the respondents. Forty five (45) questionnaires have been found to be incomplete and have been excluded from the analysis. Remaining three hundred and twenty eight questionnaires have been used for the analysis. The objective of this study has been to analyse the various services availed by retail equity investors from the stockbrokers while dealing in securities market.
This analysis has been done to check whether there is any significant difference in the opinion equity investors across their demographics regarding the stockbrokers' services availed by them.

H01: There is no difference in the opinion of the equity investors as per their gender regarding the stockbrokers services availed by them.

H02: There is no significant difference in the opinion of the equity investors regarding the various stockbroker services availed by them while making equity investment decision across their age.

H03: There is no significant difference in the opinion of the equity investors regarding the various stockbroker services availed by them while making equity investment decision across their educational qualification.

H04: There is no significant difference in the opinion of the equity investors regarding the various stockbroker services availed by them while making equity investment decision across their occupation.

H05: There is no significant difference in the opinion of the equity investors regarding the various stockbroker services availed by them while making equity investment decision across their income.

H06: There is no significant difference in the opinion of the equity investors regarding the various stockbroker services availed by them while making equity investment decision across their location background.

\section{DATA ANALYSIS}

The demographic profile of the equity investors has been presented in Table 1. The purpose of this profile is to obtain a visualization of the equity investors responding to the profile. The gender wise analysis shows that the percentage of males has been found to be $57.9 \%$ and the percentage of females has been $42.1 \%$. The table 1 shows that the age group of up to 35 years represents $46.6 \%$ of the respondents. The age group of $35-50$ years represents $24.4 \%$ of the 
respondents; while above 50 years of age category represents $29.0 \%$ of the respondents.

As set out in table 1 the largest segment of respondents i.e. $46.0 \%$ has been holding master's degree followed by respondents with bachelor's degree from college who have made up the second largest group at $31.7 \%$ while remaining $18.3 \%$ of the respondents have professional qualification such as doctors, engineers, lawyers etc. The smallest group comprises of those who have qualification up to under graduation i.e. $4.0 \%$. Therefore, it has been found that $96.0 \%$ of the total respondents are graduates and above.

Table 1 : Demographic Profile of Respondents

\begin{tabular}{|c|c|c|c|}
\hline Demographic Variable & Category & Frequency & Percentage \\
\hline \multirow[t]{3}{*}{ Gender } & Male & 190 & 57.9 \\
\hline & Female & 138 & 42.1 \\
\hline & Total & 328 & 100 \\
\hline \multirow[t]{4}{*}{ Age in years } & Up to 35 & 153 & 46.6 \\
\hline & $35-50$ & 80 & 24.4 \\
\hline & Above 50 & 95 & 29.0 \\
\hline & Total & 328 & 100 \\
\hline \multirow[t]{5}{*}{ Educational Background } & Professional & 60 & 18.3 \\
\hline & Post Graduate & 151 & 46.0 \\
\hline & Graduate & 104 & 31.7 \\
\hline & Under Graduate & 13 & 4.0 \\
\hline & Total & 328 & 100 \\
\hline \multirow[t]{6}{*}{ Occupation } & Academician & 63 & 19.2 \\
\hline & Banker and Insurer & 70 & 21.3 \\
\hline & CA, CS, CWA and financial consultant & 34 & 10.4 \\
\hline & Businessman & 90 & 27.4 \\
\hline & Others & 71 & 21.6 \\
\hline & Total & 328 & 100 \\
\hline \multirow[t]{5}{*}{ Income in Rupees } & Less than $2,00,000$ & 18 & 5.5 \\
\hline & $2,00,001-5,00,000$ & 89 & 27.1 \\
\hline & $5,00,001-10,00,000$ & 157 & 47.9 \\
\hline & More Than 10,00,000 & 64 & 19.5 \\
\hline & Total & 328 & 100 \\
\hline \multirow[t]{5}{*}{ City } & Amritsar & 82 & 25 \\
\hline & Jalandhar & 82 & 25 \\
\hline & Ludhiana & 82 & 25 \\
\hline & Mohali & 82 & 25 \\
\hline & Total & 328 & 100 \\
\hline
\end{tabular}


The occupation wise analysis shows that majority of the respondents are from business class (27.4\%) followed by others $(21.6 \%$ comprising of doctors, engineers, lawyers, inspectors and persons working at clerical posts in various offices etc.) followed by bankers and insurers (21.3\%) and academicians (19.2\%). The smallest group of respondents on the basis of occupation is formed by chartered accountants, company secretaries, cost and work accountants and financial consultants i.e. $10.4 \%$. Therefore, by selecting this sample, an attempt has been made to represent the population of the study.

Income wise analysis reveals that the respondents in the Rs.5,00,001-10,00,000 category of income represent the largest group of respondents at $47.9 \%$. Those respondents earning between Rs.2,00,001-
$5,00,000$ represent the second largest group at $27.1 \%$. The third largest group is of the respondents having income more than Rs.10,00,000 at $19.5 \%$ and the smallest number of respondents are in the income group of less than Rs.2,00,000 at 5.5\%. The table reveals that equal number of respondents i.e. 82 have been taken from each district i.e. Amritsar, Jalandhar, Ludhiana and Mohali.

Retail equity investors avail the services of stockbrokers while investing in primary market and secondary market. The table 2 highlights that one hundred and eighty nine i.e. $57.6 \%$ of the investors take help of stockbrokers while investing in primary market and three hundred and twenty one $(97.9 \%)$ i.e. almost all of the respondents take the help of the stockbrokers while investing in secondary market.

Table 2 : Stockbrokers Services availed by Retail Equity Investors while Investing

\begin{tabular}{|l|c|c|c|}
\hline Particulars & Yes & No & Total \\
\hline Primary Market & $189(57.6 \%)$ & $139(42.4 \%)$ & 328 \\
\hline Secondary Market & $321(97.9 \%)$ & $7(2.1 \%)$ & 328 \\
\hline
\end{tabular}

Note: Figures in parentheses indicate percentages

Retail equity investors have been availing the services of stockbrokers for long time. The table 3 highlights that most of the retail equity investors i.e. two hundred and nineteen $(66.8 \%)$ have been availing the services of stockbrokers for more than five years. Sixty six $(20.1 \%)$ retail equity investors have been availing the services of stockbrokers for three to five years and twenty four $(7.3 \%)$ have been availing the services of stockbrokers for one to three years while nineteen $(5.8 \%)$ retail equity investors have been availing the services of stockbrokers for less than one year.

Table 3 : For How Long Retail Equity Investors have been availing the Services of Stockbrokers

\begin{tabular}{|l|c|}
\hline \multicolumn{1}{|c|}{ Particulars } & Frequency \\
\hline Less than one year & $19(5.8 \%)$ \\
\hline $1-3$ years & $24(7.3 \%)$ \\
\hline 3-5 years & $66(20.1 \%)$ \\
\hline More than 5 years & $219(66.8 \%)$ \\
\hline Total & $328(100 \%)$ \\
\hline
\end{tabular}

Note: Figures in parentheses indicate percentages 
Registration of the stockbrokers and sub-brokers has been made compulsory as per the Securities and Exchange Board of India (Stockbrokers and Subbrokers) Regulations, 1992. The table 4 reveals that almost all the equity investors i.e. three hundred and twenty four $(98.8 \%)$ have been aware of the fact that registration of the stockbrokers has been made compulsory. Only four (1.2\%) retail equity investors are not aware of the fact that registration of stockbrokers has been made compulsory.

Table 4 : Awareness of Retail Equity Investors regarding the fact that Registration of Stockbrokers has been made Compulsory

\begin{tabular}{|c|c|}
\hline Particulars & Frequency \\
\hline Yes & $324(98.8 \%)$ \\
\hline No & $4(1.2 \%)$ \\
\hline Total & $328(100 \%)$ \\
\hline
\end{tabular}

Note: Figures in parentheses indicate percentages

The table 5 reveals that out of three hundred and twenty four equity investors are aware of the fact that registration of the stockbrokers has been made compulsory. Three hundred and twenty three equity investors are aware of the fact that they are dealing with registered stockbrokers while one (0.31) retail equity investor does not know whether the stockbroker with whom he is dealing is registered or not.

Table 5 : Awareness amongst Retail Equity Investors whether the Stockbroker with whom They are Trading is Registered or Not

\begin{tabular}{|c|c|}
\hline Particulars & Frequency \\
\hline Yes & $323(99.69 \%)$ \\
\hline Do not know & $1(0.31 \%)$ \\
\hline Total & $324(100 \%)$ \\
\hline
\end{tabular}

Note: Figures in parentheses indicate percentages

The table 6 reveals that three hundred and twenty $(97.6 \%)$ retail equity investors are aware of the guidelines laid down by SEBI for regulation of stockbrokers while eight $(2.4 \%)$ retail equity investors are not aware of these guidelines.

The table 7 reveals that out of three hundred and twenty retail equity investors who are known to the fact that guidelines for the regulation of stockbroker have been issued by SEBI, eleven respondents say that their stockbrokers always follow the guidelines. Three hundred $(93.75 \%)$ respondents state that their stockbrokers often follow the guidelines laid down by SEBI and nine (2.8\%) respondents have highlighted that their stockbrokers rarely follow the guidelines.

Table 6 : Awareness amongst Retail Equity Investors regarding the Guidelines laid down by SEBI for the Regulation of Stockbrokers

\begin{tabular}{|c|c|}
\hline Particulars & Frequency \\
\hline Yes & $320(97.6 \%)$ \\
\hline No & $8(2.4 \%)$ \\
\hline Total & $328(100 \%)$ \\
\hline
\end{tabular}

Note: Figures in parentheses indicate percentages

Table 7 : Retail Equity Investors' View regarding whether Stockbrokers follow the Norms Lay down by SEBI

\begin{tabular}{|c|c|}
\hline Particulars & Frequency \\
\hline Always & $11(3.44 \%)$ \\
\hline Often & $300(93.75 \%)$ \\
\hline Rarely & $9(2.81 \%)$ \\
\hline Never & $0(0.0 \%)$ \\
\hline Total & $320(100 \%)$ \\
\hline
\end{tabular}

Note: Figures in parentheses indicate percentages

Respondents have also been asked whether the failure of the stockbrokers to follow norms affect their investment decision. The table 8 reveals that most of the respondents i.e. three hundred and five 
(93\%) have replied that it will not affect their investment decision. Only twenty three (7.0\%) respondents have replied that it will affect their investment decision. It means that respondents are only bothered about their concerns like safety, marketability, regular return and growth. They are least bothered about regulatory measures taken by the government and SEBI for their benefit. Respondents will take legal action only when something wrong happen to them. Respondents do not take precautionary measures.
Table 8 : Failure of the Stockbrokers to follow Norms affects Retail Equity Investor Investment Decision

\begin{tabular}{|c|c|}
\hline Particulars & Frequency \\
\hline Yes & $23(7.0 \%)$ \\
\hline No & $305(93.0 \%)$ \\
\hline Total & $328(100 \%)$ \\
\hline
\end{tabular}

Note: Figures in parentheses indicate percentages The table 9 is revealing how the retail equity investors' investment decision gets influenced by the failure of the stockbroker to follow norms lay down

by SEBI. Out of these twenty three respondents, fifteen $(65.21 \%)$ respondents say that they will change their stockbrokers and six $(26.09 \%)$ respondents say that they will change their stockbrokers and report to SEBI. One respondent says that getting wrong information leads to wrong investment decision and one says that money get blocked.

Table 9 : Retail Equity Investors' Investment Decisions get Influenced

\begin{tabular}{|l|c|}
\hline \multicolumn{1}{|c|}{ Particulars } & Frequency \\
\hline Changed my stockbroker & $15(65.21 \%)$ \\
\hline Changed my stockbroker and report to SEBI & $6(26.09 \%)$ \\
\hline Getting wrong information leads to wrong investment decision & $1(4.35 \%)$ \\
\hline Money get blocked & $1(4.35 \%)$ \\
\hline Total & $23(100 \%)$ \\
\hline
\end{tabular}

Note: Figures in parentheses indicate percentages

Stockbrokers provide various valuable services to the investors like provide advice about the securities as part of their regular business, execute shares and mutual fund transactions on the client's behalf, recommend specific investments, provide retirement and general financial planning etc. By taking this into consideration, this study has been carried out to analyse the various services availed by retail equity investors from the stockbrokers while dealing in securities market. The respondents have been given a list of nine services and have been asked to rate these on five point Likert scale ranging from five to one, where five stands for 'Always' four stands for 'Often' three stands for 'Occasionally' two stands for 'Rarely' and one stands for 'Never' on the basis of their usage. The ratings have been given by the retail equity investors on all nine services and have been analysed in terms of numbers and percentages of retail equity investors and mean scores, the results of which are presented in table 10.

The table 10 highlights the frequency of services availed by the retail equity investors while dealing in equity shares in terms of numbers and percentages of equity investors and mean scores of services. It has been found from the table 10 that a major chunk of respondents have rated all the services as often, occasionally and always availed by them. The highest mean scores has been found for the variable provide advice about the securities as a part of their regular business (4.02) followed by execute shares and mutual fund transactions on the client's behalf (3.97), recommend specific investments (3.97), typically charge commission on purchases or trades 
that the client makes (3.81), required by law to act in the client's best interest (3.65), required by law to disclose any conflict of interest (3.55), provide retirement planning (3.54), provide general financial planning (3.51) and typically paid commission based on the amount of assets that the client holds (3.24). Therefore, it can be analysed from the table 10 that most of the respondents deal in the share market with the help of stockbrokers.

Table 10 : Investors' Ratings on the Stockbroker Services availed by Them on Five Point Likert Scale

\begin{tabular}{|c|c|c|c|c|c|c|c|c|}
\hline S. No. & Services & Always & Often & Occasionally & Rarely & Never & $\mathbf{N}$ & Mean \\
\hline 1 & $\begin{array}{l}\text { Provide advice about the securities as a part of their } \\
\text { regular business }\end{array}$ & $19(5.8 \%)$ & $297(90.5 \%)$ & $10(3.0 \%)$ & $2(0.6 \%)$ & - & 328 & 4.02 \\
\hline 2 & $\begin{array}{l}\text { Execute shares and mutual fund transactions on the } \\
\text { client's behalf }\end{array}$ & $12(3.7 \%)$ & $296(90.2 \%)$ & $19(5.8 \%)$ & $1(0.3 \%)$ & - & 328 & 3.97 \\
\hline 3 & Recommend specific investments & $16(4.9 \%)$ & $289(88.1 \%)$ & $19(5.8 \%)$ & $4(1.2 \%)$ & - & 328 & 3.97 \\
\hline 4 & Provide retirement planning & $5(1.5 \%)$ & $180(54.9 \%)$ & $132(40.2 \%)$ & $9(2.7 \%)$ & $2(0.6 \%)$ & 328 & 3.54 \\
\hline 5 & Provide general financial planning & $8(2.4 \%)$ & $168(51.2 \%)$ & $137(41.8 \%)$ & $12(3.7 \%)$ & $3(0.9 \%)$ & 328 & 3.51 \\
\hline 6 & $\begin{array}{l}\text { Typically charge commission on purchases or trade } \\
\text { that the client makes }\end{array}$ & $10(3.0 \%)$ & $250(76.2 \%)$ & $63(19.2 \%)$ & $5(1.5 \%)$ & - & 328 & 3.81 \\
\hline 7 & $\begin{array}{l}\text { Typically paid commission based on the amount of } \\
\text { assets that the client holds }\end{array}$ & $12(3.7 \%)$ & $159(48.5 \%)$ & $54(16.5 \%)$ & $101(30.8 \%)$ & $2(0.6 \%)$ & 328 & 3.24 \\
\hline 8 & Required by law to act in the client's best interest & $82(25.0 \%)$ & $81(24.7 \%)$ & $136(41.5 \%)$ & $27(8.2 \%)$ & $2(0.6 \%)$ & 328 & 3.65 \\
\hline 9 & Required by law to disclose any conflict of interests & $82(25.0 \%)$ & $76(23.2 \%)$ & $113(34.5 \%)$ & $54(16.5 \%)$ & $3(0.9 \%)$ & 328 & 3.55 \\
\hline
\end{tabular}

Note: Figures in parentheses indicate percentages

Ninety males and one hundred and thirty eight females) on the services availed by them has been comparatively analysed using independent sample T-test. The respondents have been asked to rate the services on a five point Likert scale ranging from five to one where five stands for 'Always' four stands for 'Often' three stands for 'Occasionally' two stands for 'Rarely' and one stands for 'Never'. Hence, it has been decided to study such relationships in this section. This analysis has been done to check whether there is any significant difference in the opinion of male and female equity investors regarding the stockbrokers services availed by them.

To test this hypothesis, independent sample T-test has been performed, the results of which are shown in the table 11. The table presents the comparative picture of the equity investors as regards their gender with respect to the stockbrokers services availed by them. The table 11 depicts the descriptives (mean and standard deviation) and tstatistic of the differences together with the level of significance.

Table 11 : Difference amongst Retail Equity Investors with regard to the Services availed by them in Relation to the Stockbrokers across their Gender

\begin{tabular}{|c|c|c|c|c|c|c|}
\hline S. No. & Services & $\begin{array}{c}\text { Levene's Test } \\
\text { for Equality } \\
\text { of Variance F } \\
\text { (Significance) }\end{array}$ & Groups & $\begin{array}{c}\text { Mean } \\
\text { (Standard } \\
\text { Deviation }\end{array}$ & $\begin{array}{c}\text { T- } \\
\text { statistic } \\
\text { (p- } \\
\text { value) }\end{array}$ & Remarks \\
\hline \multirow[t]{2}{*}{1} & \multirow{2}{*}{$\begin{array}{l}\text { Provide advice } \\
\text { about the securities } \\
\text { as a } \\
\text { part of their regular } \\
\text { business }\end{array}$} & \multirow{2}{*}{$.013(0.909)$} & Male & $4.00(0.37)$ & \multirow[b]{2}{*}{$\begin{array}{l}-0.964 \\
(0.336)\end{array}$} & \multirow{2}{*}{$\begin{array}{c}\text { No } \\
\text { significant } \\
\text { difference } \\
\text { exists }\end{array}$} \\
\hline & & & Female & $4.04(0.28)$ & & \\
\hline
\end{tabular}




\begin{tabular}{|c|c|c|c|c|c|c|}
\hline \multirow[t]{2}{*}{2} & \multirow{2}{*}{$\begin{array}{l}\text { Execute shares and } \\
\text { mutual fund } \\
\text { transactions } \\
\text { on the client's } \\
\text { behalf }\end{array}$} & \multirow[t]{2}{*}{$1.48(0.225)$} & Male & $3.96(0.34)$ & \multirow[b]{2}{*}{$\begin{array}{l}-0.956 \\
(0.340)\end{array}$} & \multirow{2}{*}{$\begin{array}{c}\text { No } \\
\text { significant } \\
\text { difference } \\
\text { exists }\end{array}$} \\
\hline & & & Female & $3.99(0.31)$ & & \\
\hline \multirow[t]{2}{*}{3} & \multirow{2}{*}{$\begin{array}{l}\text { Recommend } \\
\text { specific investments }\end{array}$} & \multirow[t]{2}{*}{$5.73(0.017)$} & Male & $3.93(0.42)$ & \multirow{2}{*}{$\begin{array}{c}-1.957 \\
(0.051)^{*}\end{array}$} & \multirow{2}{*}{$\begin{array}{l}\text { Significant } \\
\text { difference } \\
\text { exists }\end{array}$} \\
\hline & & & Female & $4.01(0.34)$ & & \\
\hline \multirow[t]{2}{*}{4} & \multirow{2}{*}{$\begin{array}{l}\text { Provide retirement } \\
\text { planning }\end{array}$} & \multirow[t]{2}{*}{$4.15(0.04)$} & Male & $3.51(0.65)$ & \multirow[b]{2}{*}{$\begin{array}{l}-1.231 \\
(0.219)\end{array}$} & \multirow{2}{*}{$\begin{array}{c}\text { No } \\
\text { significant } \\
\text { difference } \\
\text { exists }\end{array}$} \\
\hline & & & Female & $3.59(0.55)$ & & \\
\hline \multirow[t]{2}{*}{5} & \multirow{2}{*}{$\begin{array}{l}\text { Provide general } \\
\text { financial planning }\end{array}$} & \multirow[t]{2}{*}{$5.75(0.017)$} & Male & $3.47(0.71)$ & \multirow[b]{2}{*}{$\begin{array}{l}-1.091 \\
(0.276)\end{array}$} & \multirow{2}{*}{$\begin{array}{c}\text { No } \\
\text { significant } \\
\text { difference } \\
\text { exists }\end{array}$} \\
\hline & & & Female & $3.55(0.57)$ & & \\
\hline \multirow[t]{2}{*}{6} & & $1.583(0.209)$ & Male & $3.79(0.52)$ & & \\
\hline & $\begin{array}{l}\text { Typically charge } \\
\text { commission on } \\
\text { purchases or trade } \\
\text { that the client } \\
\text { makes }\end{array}$ & & Female & $3.83(0.47)$ & $\begin{array}{l}-0.563 \\
(0.574)\end{array}$ & $\begin{array}{c}\text { No } \\
\text { significant } \\
\text { difference } \\
\text { exists }\end{array}$ \\
\hline \multirow[t]{2}{*}{7} & \multirow{2}{*}{$\begin{array}{l}\text { Typically paid } \\
\text { commission based } \\
\text { on the amount of } \\
\text { assets } \\
\text { that the client holds }\end{array}$} & \multirow[t]{2}{*}{$0.010(0.921)$} & Male & $3.25(0.96)$ & \multirow[b]{2}{*}{$\begin{array}{c}0.213 \\
(0.832)\end{array}$} & \multirow{2}{*}{$\begin{array}{c}\text { No } \\
\text { significant } \\
\text { difference } \\
\text { exists }\end{array}$} \\
\hline & & & Female & $3.22(0.95)$ & & \\
\hline \multirow[t]{2}{*}{8} & \multirow{2}{*}{$\begin{array}{l}\text { Required by law to } \\
\text { act in the client's } \\
\text { best interest }\end{array}$} & \multirow[t]{2}{*}{$4.208(0.041)$} & Male & $3.62(0.93)$ & \multirow[b]{2}{*}{$\begin{array}{l}-0.797 \\
(0.426)\end{array}$} & \multirow{2}{*}{$\begin{array}{c}\text { No } \\
\text { significant } \\
\text { difference } \\
\text { exists }\end{array}$} \\
\hline & & & Female & $3.70(1.01)$ & & \\
\hline \multirow[t]{2}{*}{9} & \multirow{2}{*}{$\begin{array}{l}\text { Required by law to } \\
\text { disclose any conflict } \\
\text { of interests }\end{array}$} & \multirow[t]{2}{*}{$3.151(0.077)$} & Male & $3.52(1.04)$ & \multirow[b]{2}{*}{$\begin{array}{l}-0.552 \\
(0.581)\end{array}$} & \multirow{2}{*}{$\begin{array}{c}\text { No } \\
\text { significant } \\
\text { difference } \\
\text { exists }\end{array}$} \\
\hline & & & Female & 3.59 (1.11) & & \\
\hline
\end{tabular}

*10\% level of significance

It is found that female equity investors have given four point zero one (4.01) average rating to recommend specific investments. A significant difference is found in the opinion of female and male equity investors as far as the service of recommend specific investment is concerned. Male equity investors rate this service at three point nine three (3.93). Whereas in case of the rest of the services like provide advice about the securities as part of their regular business, execute shares and mutual fund transactions on the client's behalf, provide retirement and general financial planning, typically charge commission on purchases or trades that the client makes etc. the differences are found to be insignificant.

An attempt has been made in this section to investigate the differences, if any amongst equity investors regarding various services availed by them in relation to stockbrokers while making investment decision across their demographics variables. This analysis has been done by using one way ANOVA, for which stockbroker services availed by equity investors are measured on five point Likert scale 
ranging from five to one (where five stands for 'Always' four stands for 'Often' three stands for 'Occasionally' two stands for 'Rarely' and one stands for 'Never'). These services have been taken as dependent variable and demographics of the retail equity investors such as age, education qualification, occupation, income and location background have been taken as independent variable.

Table 12 : Difference amongst Retail Equity Investors with regard to the Services availed by them in Relation to the Stockbrokers across their Age

\begin{tabular}{|c|c|c|c|c|c|}
\hline S. No. & Services & Groups & $\begin{array}{c}\text { Mean } \\
\text { (Standard } \\
\text { Deviation) } \\
\end{array}$ & $\begin{array}{c}\text { F- } \\
\text { statistic } \\
\text { (p value) }\end{array}$ & Remarks \\
\hline \multirow[t]{3}{*}{1} & \multirow{3}{*}{$\begin{array}{l}\text { Provide advice about the } \\
\text { securities as a part of their } \\
\text { regular business }\end{array}$} & Less than 35 & $4.02(0.42)$ & \multirow{3}{*}{$0.47(0.63)$} & \multirow{3}{*}{$\begin{array}{c}\text { No significant } \\
\text { difference } \\
\text { exists }\end{array}$} \\
\hline & & $35-50$ & $4.04(0.25)$ & & \\
\hline & & More than 50 & $3.99(0.23)$ & & \\
\hline \multirow[t]{3}{*}{2} & \multirow{3}{*}{$\begin{array}{l}\text { Execute shares and } \\
\text { mutual fund transactions } \\
\text { on the client's behalf }\end{array}$} & Less than 35 & $3.97(0.41)$ & \multirow{3}{*}{$0.01(0.99)$} & \multirow{3}{*}{$\begin{array}{l}\text { No significant } \\
\text { difference } \\
\text { exists }\end{array}$} \\
\hline & & $35-50$ & $3.97(0.22)$ & & \\
\hline & & More than 50 & $3.97(0.23)$ & & \\
\hline \multirow[t]{3}{*}{3} & \multirow{3}{*}{$\begin{array}{l}\text { Recommend specific } \\
\text { investments }\end{array}$} & Less than 35 & $3.95(0.48)$ & \multirow{3}{*}{$0.19(0.83)$} & \multirow{3}{*}{$\begin{array}{c}\text { No significant } \\
\text { difference } \\
\text { exists }\end{array}$} \\
\hline & & $35-50$ & $3.99(0.29)$ & & \\
\hline & & More than 50 & $3.97(0.31)$ & & \\
\hline \multirow[t]{3}{*}{4} & \multirow{3}{*}{$\begin{array}{l}\text { Provide retirement } \\
\text { planning }\end{array}$} & Less than 35 & $3.49(0.69)$ & \multirow{3}{*}{$0.71(0.49)$} & \multirow{3}{*}{$\begin{array}{c}\text { No significant } \\
\text { difference } \\
\text { exists }\end{array}$} \\
\hline & & $35-50$ & $3.57(0.52)$ & & \\
\hline & & More than 50 & $3.58(0.52)$ & & \\
\hline \multirow[t]{3}{*}{5} & \multirow{3}{*}{$\begin{array}{l}\text { Provide general financial } \\
\text { planning }\end{array}$} & Less than 35 & $3.48(0.73)$ & \multirow{3}{*}{$0.40(0.67)$} & \multirow{3}{*}{$\begin{array}{l}\text { No significant } \\
\text { difference } \\
\text { exists }\end{array}$} \\
\hline & & $35-50$ & $3.56(0.57)$ & & \\
\hline & & More than 50 & $3.49(0.58)$ & & \\
\hline \multirow[t]{3}{*}{6} & \multirow{3}{*}{$\begin{array}{l}\text { Typically charge } \\
\text { commission on purchases } \\
\text { or trade that the client } \\
\text { makes }\end{array}$} & Less than 35 & $3.76(0.59)$ & \multirow{3}{*}{$1.10(0.33)$} & \multirow{3}{*}{$\begin{array}{l}\text { No significant } \\
\text { difference } \\
\text { exists }\end{array}$} \\
\hline & & $35-50$ & $3.84(0.40)$ & & \\
\hline & & More than 50 & $3.85(0.38)$ & & \\
\hline \multirow[t]{3}{*}{7} & \multirow{3}{*}{$\begin{array}{l}\text { Typically paid } \\
\text { commission based on the } \\
\text { amount of assets that the } \\
\text { client holds }\end{array}$} & Less than 35 & $3.27(0.97)$ & \multirow{3}{*}{$0.59(0.56)$} & \multirow{3}{*}{$\begin{array}{l}\text { No significant } \\
\text { difference } \\
\text { exists }\end{array}$} \\
\hline & & $35-50$ & $3.14(0.95)$ & & \\
\hline & & More than 50 & $3.26(0.92)$ & & \\
\hline \multirow[t]{3}{*}{8} & \multirow{3}{*}{$\begin{array}{l}\text { Required by law to act in } \\
\text { the client's best interest }\end{array}$} & Less than 35 & $3.65(0.94)$ & \multirow{3}{*}{$2.07(0.13)$} & \multirow{3}{*}{$\begin{array}{l}\text { No significant } \\
\text { difference } \\
\text { exists }\end{array}$} \\
\hline & & $35-50$ & $3.81(0.94)$ & & \\
\hline & & More than 50 & $3.51(1.01)$ & & \\
\hline 9 & Required by law to & Less than 35 & $3.57(0.99)$ & & No significant \\
\hline & disclose any conflict of & $35-50$ & $3.68(1.11)$ & $1.64(0.19)$ & difference \\
\hline & interests & More than 50 & $3.40(1.12)$ & & exists \\
\hline
\end{tabular}

The results of one way ANOVA are presented in table 12 which demonstrate the probable impact of the equity investors' age on the level of stockbroker services availed by them while making financial transactions. The services under review are mentioned in table 12 like provide advice about the securities as a part of their regular business, execute shares and mutual fund transactions on the client's behalf, recommend specific investments, provide retirement and general financial planning, typically charge commission on purchases or trades that client makes, typically paid commission based on the amount of assets that client holds, required by law to act in the client's best interest and required by law to disclose any conflicts of interest exhibit no significant difference with reference to various age groups. So, 
the null hypothesis is accepted.

The table 13 presents the results of one way ANOVA which demonstrates the impact of retail equity investors' education on the level of stockbroker services availed by them. The table 13 has revealed no significant impact of education on the level of stockbroker services availed by retail equity investors such as provide advice about the securities as a part of their regular business, recommend specific investment, provide retirement and general financial planning, typically paid commission based on the amount of assets that the client holds, required by law to act in the client's best interest etc. So, the null hypothesis is accepted except in case of execute shares and mutual fund transactions on the client's behalf (0.04) and typically charge commission on purchases or trades that the client makes (0.012). In the case of these services the null hypothesis is rejected at five percent level of significance.

Table 13 : Difference amongst Retail Equity Investors with regard to the Services availed by them in Relation to the Stockbrokers across their Education

\begin{tabular}{|c|c|c|c|c|c|}
\hline S. No. & Services & Groups & $\begin{array}{c}\text { Mean } \\
\text { (Standard } \\
\text { Deviation) } \\
\end{array}$ & $\begin{array}{l}\text { F statistic (p } \\
\text { value) }\end{array}$ & Remarks \\
\hline \multirow[t]{4}{*}{1} & \multirow{4}{*}{$\begin{array}{l}\text { Provide advice about } \\
\text { the securities as a } \\
\text { part of their regular } \\
\text { business }\end{array}$} & Professional & $4.07(0.31)$ & \multirow{4}{*}{$0.79(0.50)$} & \multirow{4}{*}{$\begin{array}{l}\text { No significant } \\
\text { difference } \\
\text { exists }\end{array}$} \\
\hline & & Post Graduate & $4.00(0.35)$ & & \\
\hline & & Graduate & $4.00(0.34)$ & & \\
\hline & & $\begin{array}{l}\text { Under } \\
\text { Graduate }\end{array}$ & $4.08(0.28)$ & & \\
\hline \multirow[t]{4}{*}{2} & \multirow{4}{*}{$\begin{array}{l}\text { Execute shares and } \\
\text { mutual fund } \\
\text { transactions on the } \\
\text { client's behalf }\end{array}$} & Professional & $4.07(0.25)$ & \multirow{4}{*}{$2.76(0.04)^{\star *}$} & \multirow{4}{*}{$\begin{array}{l}\text { Significant } \\
\text { difference } \\
\text { exists }\end{array}$} \\
\hline & & Post Graduate & $3.95(0.36)$ & & \\
\hline & & Graduate & $3.94(0.31)$ & & \\
\hline & & $\begin{array}{l}\text { Under } \\
\text { Graduate }\end{array}$ & $4.08(0.28)$ & & \\
\hline \multirow[t]{4}{*}{3} & \multirow{4}{*}{$\begin{array}{l}\text { Recommend specific } \\
\text { investments }\end{array}$} & Professional & $4.02(0.34)$ & \multirow{4}{*}{$0.49(0.68)$} & \multirow{4}{*}{$\begin{array}{l}\text { No significant } \\
\text { difference } \\
\text { exists }\end{array}$} \\
\hline & & Post Graduate & $3.96(0.39)$ & & \\
\hline & & Graduate & $3.94(0.41)$ & & \\
\hline & & $\begin{array}{l}\text { Under } \\
\text { Graduate }\end{array}$ & $4.00(0.41)$ & & \\
\hline \multirow[t]{4}{*}{4} & \multirow{4}{*}{$\begin{array}{l}\text { Provide retirement } \\
\text { planning }\end{array}$} & Professional & $3.57(0.69)$ & \multirow{4}{*}{$0.32(0.81)$} & \multirow{4}{*}{$\begin{array}{l}\text { No significant } \\
\text { difference } \\
\text { exists }\end{array}$} \\
\hline & & Post Graduate & $3.54(0.61)$ & & \\
\hline & & Graduate & $3.54(0.57)$ & & \\
\hline & & $\begin{array}{l}\text { Under } \\
\text { Graduate }\end{array}$ & $3.38(0.51)$ & & \\
\hline \multirow[t]{4}{*}{5} & \multirow{3}{*}{$\begin{array}{l}\text { Provide general } \\
\text { financial planning }\end{array}$} & Professional & $3.48(0.75)$ & \multirow{3}{*}{$0.60(0.61)$} & \multirow{3}{*}{$\begin{array}{c}\text { No significant } \\
\text { difference } \\
\text { exists }\end{array}$} \\
\hline & & Post Graduate & $3.54(0.64)$ & & \\
\hline & & Graduate & $3.49(0.61)$ & & \\
\hline & & $\begin{array}{l}\text { Under } \\
\text { Graduate }\end{array}$ & $3.31(0.75)$ & & \\
\hline
\end{tabular}




\begin{tabular}{|c|c|c|c|c|c|}
\hline \multirow[t]{4}{*}{6} & \multirow{4}{*}{$\begin{array}{l}\text { Typically charge } \\
\text { commission on } \\
\text { purchases or trade } \\
\text { that the client makes }\end{array}$} & Professional & $3.97(0.37)$ & \multirow{4}{*}{$3.69(0.012)^{* *}$} & \multirow{4}{*}{$\begin{array}{l}\text { Significant } \\
\text { difference } \\
\text { exists }\end{array}$} \\
\hline & & Post Graduate & $3.82(0.52)$ & & \\
\hline & & Graduate & $3.71(0.51)$ & & \\
\hline & & $\begin{array}{l}\text { Under } \\
\text { Graduate }\end{array}$ & $3.69(0.48)$ & & \\
\hline \multirow[t]{4}{*}{7} & \multirow{4}{*}{$\begin{array}{l}\text { Typically paid } \\
\text { commission based on } \\
\text { the amount of assets } \\
\text { that the client holds }\end{array}$} & Professional & $3.25(0.95)$ & \multirow{4}{*}{$1.09(0.35)$} & \multirow{4}{*}{$\begin{array}{l}\text { No significant } \\
\text { difference } \\
\text { exists }\end{array}$} \\
\hline & & Post Graduate & $3.32(0.94)$ & & \\
\hline & & Graduate & $3.13(0.95)$ & & \\
\hline & & $\begin{array}{l}\text { Under } \\
\text { Graduate }\end{array}$ & $3.00(1.08)$ & & \\
\hline \multirow[t]{4}{*}{8} & \multirow{4}{*}{$\begin{array}{l}\text { Required by law to } \\
\text { act in the client's best } \\
\text { interest }\end{array}$} & Professional & 3.65 (1.09) & \multirow{4}{*}{$0.94(0.42)$} & \multirow{4}{*}{$\begin{array}{l}\text { No significant } \\
\text { difference } \\
\text { exists }\end{array}$} \\
\hline & & Post Graduate & $3.61(0.96)$ & & \\
\hline & & Graduate & $3.66(0.93)$ & & \\
\hline & & $\begin{array}{l}\text { Under } \\
\text { Graduate }\end{array}$ & $4.08(0.64)$ & & \\
\hline \multirow[t]{4}{*}{9} & \multirow{4}{*}{$\begin{array}{l}\text { Required by law to } \\
\text { disclose any conflict } \\
\text { of interests }\end{array}$} & Professional & $3.55(1.21)$ & \multirow{4}{*}{$0.41(0.74)$} & \multirow{4}{*}{$\begin{array}{l}\text { No significant } \\
\text { difference } \\
\text { exists }\end{array}$} \\
\hline & & Post Graduate & $3.50(1.05)$ & & \\
\hline & & Graduate & $3.57(1.03)$ & & \\
\hline & & $\begin{array}{l}\text { Under } \\
\text { Graduate }\end{array}$ & $3.85(0.80)$ & & \\
\hline
\end{tabular}

*10 \% level of significance

**5\% level of significance

$* * * 1 \%$ level of significance

Table 14 : Difference amongst Retail Equity Investors with regard to the Services availed by them in Relation to the Stockbrokers across their Occupation

\begin{tabular}{|c|c|c|c|c|c|}
\hline S. No. & Services & Group & $\begin{array}{c}\text { Mean } \\
\text { (Standard } \\
\text { Deviation) }\end{array}$ & $\begin{array}{c}F \\
\text { statistic } \\
\text { (p value) }\end{array}$ & Remarks \\
\hline \multirow[t]{5}{*}{1} & \multirow{5}{*}{$\begin{array}{l}\text { Provide advice } \\
\text { about the securities } \\
\text { as a part of their } \\
\text { regular business }\end{array}$} & Academician & $4.01(0.38)$ & \multirow{5}{*}{$\begin{array}{c}0.56 \\
(0.69)\end{array}$} & \multirow{5}{*}{$\begin{array}{l}\text { No } \\
\text { significant } \\
\text { difference } \\
\text { exists }\end{array}$} \\
\hline & & Banker and Insurer & $4.04(0.39)$ & & \\
\hline & & CA/CS/CWA/FC & $3.94(0.24)$ & & \\
\hline & & Businessman & $4.01(0.24)$ & & \\
\hline & & Others & $4.03(0.38)$ & & \\
\hline \multirow[t]{5}{*}{2} & \multirow{5}{*}{$\begin{array}{l}\text { Execute shares and } \\
\text { mutual fund } \\
\text { transactions on the } \\
\text { client's behalf }\end{array}$} & Academician & $3.98(0.28)$ & \multirow{5}{*}{$\begin{array}{c}0.83 \\
(0.51)\end{array}$} & \multirow{5}{*}{$\begin{array}{c}\text { No } \\
\text { significant } \\
\text { difference } \\
\text { exists }\end{array}$} \\
\hline & & Banker and Insurer & $4.00(0.38)$ & & \\
\hline & & CA/CS/CWA/FC & $3.88(0.33)$ & & \\
\hline & & Businessman & $3.97(0.23)$ & & \\
\hline & & Others & $3.98(0.39)$ & & \\
\hline \multirow[t]{5}{*}{3} & \multirow{5}{*}{$\begin{array}{l}\text { Recommend specific } \\
\text { investments }\end{array}$} & Academician & $3.95(0.45)$ & \multirow{5}{*}{$\begin{array}{c}1.51 \\
(0.19)\end{array}$} & \multirow{5}{*}{$\begin{array}{c}\text { No } \\
\text { significant } \\
\text { difference } \\
\text { exists }\end{array}$} \\
\hline & & Banker and Insurer & $4.04(0.31)$ & & \\
\hline & & CA/CS/CWA/FC & $3.85(0.43)$ & & \\
\hline & & Businessman & $3.94(0.41)$ & & \\
\hline & & Others & $3.98(0.36)$ & & \\
\hline \multirow[t]{2}{*}{4} & \multirow{2}{*}{$\begin{array}{l}\text { Provide retirement } \\
\text { planning }\end{array}$} & Academician & $3.62(0.61)$ & \multirow{2}{*}{$\begin{array}{c}1.43 \\
(0.22)\end{array}$} & \multirow{2}{*}{$\begin{array}{c}\text { No } \\
\text { significant }\end{array}$} \\
\hline & & Banker and Insurer & $3.54(0.61)$ & & \\
\hline
\end{tabular}




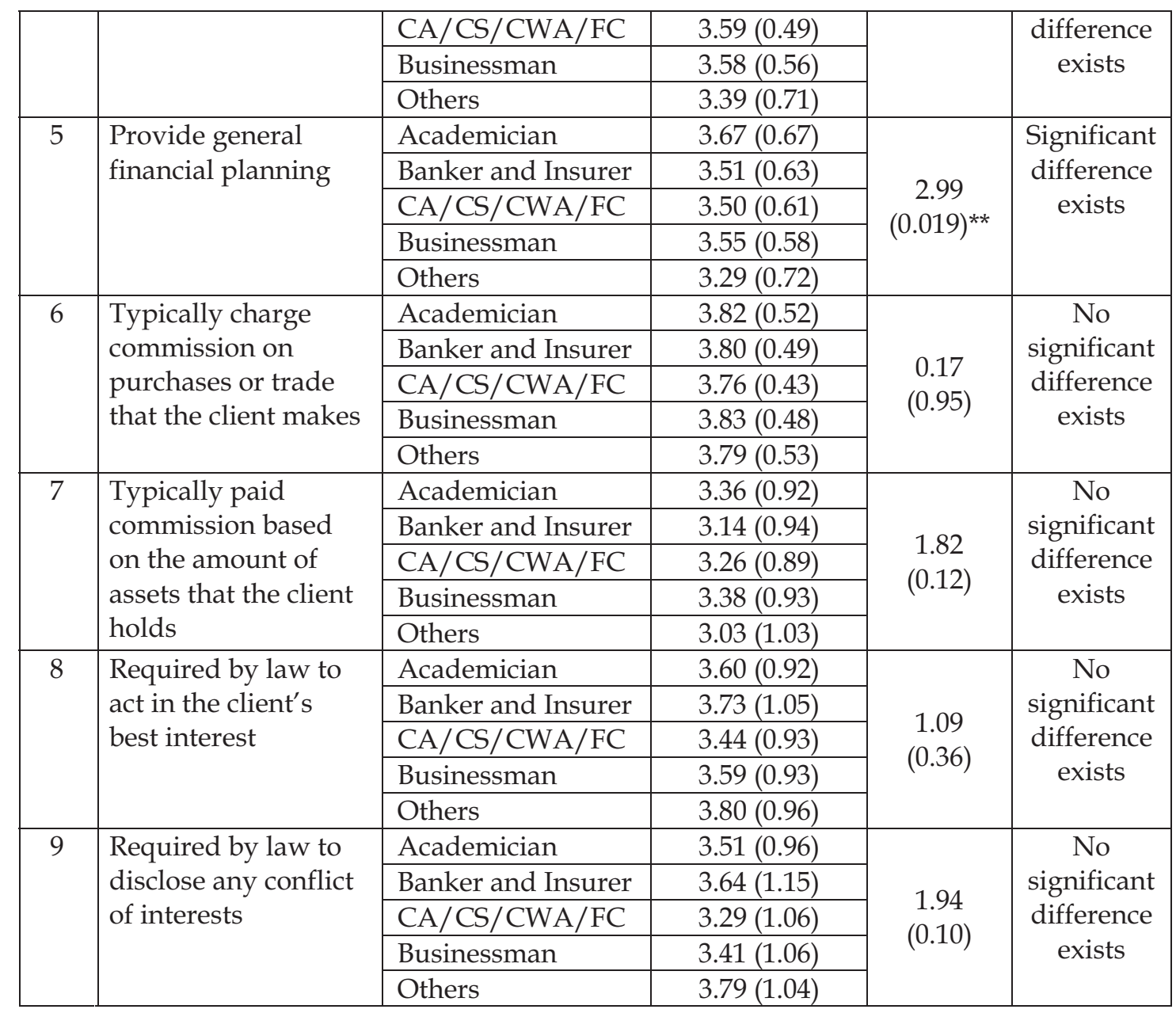

*10 \% level of significance

**5\% level of significance

$* * * 1 \%$ level of significance

The table 14 reveals the impact of equity investors occupation on the level of stockbroker services availed by them. The table highlights that there is no significant impact of occupation on the level of stockbroker services availed by retail equity investors except in case of general financial planning (0.019). The null hypothesis is rejected in this case at five percent level of significance.

Table 15 : Difference amongst Retail Equity Investors with regard to the Services availed by them in Relation to the Stockbrokers across their Income

\begin{tabular}{|c|c|c|c|c|c|}
\hline S. No. & Services & Group & $\begin{array}{c}\text { Mean } \\
\text { (Standard } \\
\text { Deviation) }\end{array}$ & $\begin{array}{l}\text { F-statistic } \\
\text { (p value) }\end{array}$ & Remarks \\
\hline \multirow[t]{4}{*}{1} & \multirow{4}{*}{$\begin{array}{l}\text { Provide advice about } \\
\text { the securities as a } \\
\text { part of their regular } \\
\text { business }\end{array}$} & Less than $2,00,000$ & $4.22(0.55)$ & \multirow{4}{*}{$2.62(0.051)^{*}$} & \multirow{4}{*}{$\begin{array}{l}\text { Significant } \\
\text { difference } \\
\text { exists }\end{array}$} \\
\hline & & $2,00,000-5,00,000$ & $4.02(0.48)$ & & \\
\hline & & $5,00,000-10,00,000$ & $4.00(0.25)$ & & \\
\hline & & More than $10,00,000$ & $3.98(0.12)$ & & \\
\hline \multirow[t]{3}{*}{2} & \multirow{3}{*}{$\begin{array}{l}\text { Execute shares and } \\
\text { mutual fund }\end{array}$} & Less than $2,00,000$ & $4.11(0.47)$ & \multirow{3}{*}{$1.18(0.32)$} & \multirow{3}{*}{$\begin{array}{c}\text { No } \\
\text { significant }\end{array}$} \\
\hline & & $2,00,000-5,00,000$ & $3.95(0.42)$ & & \\
\hline & & $5,00,000-10,00,000$ & $3.97(0.28)$ & & \\
\hline
\end{tabular}




\begin{tabular}{|c|c|c|c|c|c|}
\hline & $\begin{array}{l}\text { transactions on the } \\
\text { client's behalf }\end{array}$ & More than $10,00,000$ & $3.97(0.17)$ & & $\begin{array}{l}\text { difference } \\
\text { exists }\end{array}$ \\
\hline \multirow[t]{4}{*}{3} & \multirow{4}{*}{$\begin{array}{l}\text { Recommend specific } \\
\text { investments }\end{array}$} & Less than $2,00,000$ & $4.05(0.64)$ & \multirow{4}{*}{$0.84(0.47)$} & \multirow{4}{*}{$\begin{array}{c}\text { No } \\
\text { significant } \\
\text { difference } \\
\text { exists }\end{array}$} \\
\hline & & $2,00,000-5,00,000$ & $4.00(0.43)$ & & \\
\hline & & $5,00,000-10,00,000$ & $3.95(0.38)$ & & \\
\hline & & More than $10,00,000$ & $3.92(0.27)$ & & \\
\hline \multirow[t]{4}{*}{4} & \multirow{4}{*}{$\begin{array}{l}\text { Provide retirement } \\
\text { planning }\end{array}$} & Less than $2,00,000$ & $3.28(0.89)$ & \multirow{4}{*}{$\begin{array}{c}4.53 \\
(0.004)^{\star * *}\end{array}$} & \multirow{4}{*}{$\begin{array}{l}\text { Significant } \\
\text { difference } \\
\text { exists }\end{array}$} \\
\hline & & $2,00,000-5,00,000$ & $3.50(0.66)$ & & \\
\hline & & $5,00,000-10,00,000$ & $3.49(0.58)$ & & \\
\hline & & More than $10,00,000$ & $3.76(0.43)$ & & \\
\hline \multirow[t]{4}{*}{5} & \multirow{4}{*}{$\begin{array}{l}\text { Provide general } \\
\text { financial planning }\end{array}$} & Less than $2,00,000$ & $3.22(1.11)$ & \multirow{4}{*}{$\begin{array}{c}4.63 \\
(0.003)^{* * *}\end{array}$} & \multirow{4}{*}{$\begin{array}{l}\text { Significant } \\
\text { difference } \\
\text { exists }\end{array}$} \\
\hline & & $2,00,000-5,00,000$ & $3.48(0.71)$ & & \\
\hline & & $5,00,000-10,00,000$ & $3.45(0.60)$ & & \\
\hline & & More than $10,00,000$ & $3.75(0.44)$ & & \\
\hline \multirow[t]{4}{*}{6} & \multirow{4}{*}{$\begin{array}{l}\text { Typically charge } \\
\text { commission on } \\
\text { purchases or trade } \\
\text { that the client makes }\end{array}$} & Less than $2,00,000$ & $3.72(0.83)$ & \multirow{4}{*}{$1.49(0.22)$} & \multirow{4}{*}{$\begin{array}{l}\text { No } \\
\text { significant } \\
\text { difference } \\
\text { exists }\end{array}$} \\
\hline & & $2,00,000-5,00,000$ & $3.79(0.57)$ & & \\
\hline & & $5,00,000-10,00,000$ & $3.78(0.47)$ & & \\
\hline & & More than $10,00,000$ & $3.92(0.27)$ & & \\
\hline \multirow[t]{4}{*}{7} & \multirow{4}{*}{$\begin{array}{l}\text { Typically paid } \\
\text { commission based on } \\
\text { the amount of assets } \\
\text { that the client holds }\end{array}$} & Less than $2,00,000$ & $2.94(1.11)$ & \multirow{4}{*}{$\begin{array}{c}4.45 \\
(0.004)^{* * *}\end{array}$} & \multirow{4}{*}{$\begin{array}{l}\text { Significant } \\
\text { difference } \\
\text { exists }\end{array}$} \\
\hline & & $2,00,000-5,00,000$ & $3.16(1.01)$ & & \\
\hline & & $5,00,000-10,00,000$ & $3.16(0.93)$ & & \\
\hline & & More than $10,00,000$ & $3.61(0.79)$ & & \\
\hline \multirow[t]{4}{*}{8} & \multirow{4}{*}{$\begin{array}{l}\text { Required by law to } \\
\text { act in the client's best } \\
\text { interest }\end{array}$} & Less than $2,00,000$ & $3.83(0.78)$ & \multirow{4}{*}{$\begin{array}{c}3.14 \\
(0.025)^{* *}\end{array}$} & \multirow{4}{*}{$\begin{array}{l}\text { Significant } \\
\text { difference } \\
\text { exists }\end{array}$} \\
\hline & & $2,00,000-5,00,000$ & $3.74(1.04)$ & & \\
\hline & & $5,00,000-10,00,000$ & $3.71(0.96)$ & & \\
\hline & & More than $10,00,000$ & $3.33(0.85)$ & & \\
\hline \multirow[t]{4}{*}{9} & \multirow{4}{*}{$\begin{array}{l}\text { Required by law to } \\
\text { disclose any conflict } \\
\text { of interests }\end{array}$} & Less than $2,00,000$ & $3.72(0.89)$ & \multirow{4}{*}{$\begin{array}{c}4.77 \\
(0.003)^{\star * *}\end{array}$} & \multirow{4}{*}{$\begin{array}{l}\text { Significant } \\
\text { difference } \\
\text { exists }\end{array}$} \\
\hline & & $2,00,000-5,00,000$ & $3.61(1.12)$ & & \\
\hline & & $5,00,000-10,00,000$ & $3.67(1.02)$ & & \\
\hline & & More than $10,00,000$ & $3.11(1.04)$ & & \\
\hline
\end{tabular}

${ }^{*} 10 \%$ level of significance

**5\% level of significance

$* * * 1 \%$ level of significance

The results of one way ANOVA are presented in table 15 which demonstrate the impact of income of equity investors on the level of stockbroker services availed by them. The table 8.10 .5 highlights that there is significant impact of income on the level of stockbroker services availed by them such as provide advice about the securities as a part of their regular business (0.051), provide retirement planning (0.004), provide general financial planning (0.003), typically paid based on the amount of assets that the client holds (0.004), required by law to act in the client's best interest (0.025) and required by law to disclose any conflict of interest (0.003). The F-values of the services availed by retail equity investors have been found to be $2.62,4.53,4.63,4.45,3.14$ and 4.77 respectively. The null hypothesis is accepted in the rest of the cases like execute share and mutual fund transaction on the client's behalf, recommend specific investment and typically charge commission on purchases or trades that client makes.

The differences in the level of services like provide retirement planning (0.004), general financial planning (0.003), typically paid based on the amount of assets that client holds (0.004) and required by law to disclose any conflict of interest (0.003) on account of income are found to be statistically significant at one percent level of significance. The difference is 
found to be statistically significant at five percent level of significance in case of the service required by law to act in the client's best interest (0.025) and the difference is found to be statistically significant at ten percent level of significance for the service provide advice about the securities as a part of their regular business.

The table 16 highlights the impact of location background of retail equity investors on the level of stockbroker services availed by them. The table reveals that statistically significant differences have been found in the level of services availed by retail equity investors such as provide retirement planning, provide general financial planning, typically charge commission on purchases or trades that the client makes, typically paid based on the amount of assets that the client holds, required by law to act in the client's best interest and required by law to disclose any conflict of interest on account of location background.

The F-values of these stockbroker services availed by retail equity investors are $6.42,8.32,9.12,11.98,18.69$ and 17.07 respectively. The differences in the level of stockbroker services of retail equity investors like provide retirement planning $(0.000)$, provide general financial planning (0.000), typically charge commission on purchases or trades that the client makes (0.000), typically paid commission based on the amount of assets that the client holds (0.000) and required by law to act in the client's best interest $(0.000)$ and required by law to disclose any conflict of interest (0.00) are found to be statistically significant at one percent level of significance. The null hypothesis is accepted in the rest of the cases like provide advice about the securities as a part of their regular business, execute share and mutual fund transactions on the client's behalf and recommend specific investment.

Table 16 : Difference amongst Retail Equity Investors with regard to the Services availed by them in Relation to the Stockbrokers across their Location Background

\begin{tabular}{|c|c|c|c|c|c|}
\hline S. No. & Services & Group & $\begin{array}{c}\text { Mean } \\
\text { (Standard } \\
\text { Deviation) }\end{array}$ & $\begin{array}{l}\text { F-statistic } \\
\text { ( } p \text { value) }\end{array}$ & Remarks \\
\hline \multirow[t]{4}{*}{1} & \multirow{4}{*}{$\begin{array}{l}\text { Provide advice about } \\
\text { the securities as a part } \\
\text { of their regular business }\end{array}$} & Amritsar & $4.01(0.46)$ & \multirow{4}{*}{$0.31(0.82)$} & \multirow{4}{*}{$\begin{array}{c}\text { No significant } \\
\text { difference } \\
\text { exists }\end{array}$} \\
\hline & & Jalandhar & $4.04(0.33)$ & & \\
\hline & & Ludhiana & $4.02(0.22)$ & & \\
\hline & & Mohali & $3.99(0.29)$ & & \\
\hline \multirow[t]{4}{*}{2} & \multirow{4}{*}{$\begin{array}{l}\text { Execute shares and } \\
\text { mutual fund } \\
\text { transactions on the } \\
\text { client's behalf }\end{array}$} & Amritsar & $3.96(0.39)$ & \multirow{4}{*}{$1.49(0.22)$} & \multirow{4}{*}{$\begin{array}{l}\text { No significant } \\
\text { difference } \\
\text { exists }\end{array}$} \\
\hline & & Jalandhar & $3.91(0.39)$ & & \\
\hline & & Ludhiana & $4.01(0.25)$ & & \\
\hline & & Mohali & $4.00(0.22)$ & & \\
\hline \multirow[t]{4}{*}{3} & \multirow{4}{*}{$\begin{array}{l}\text { Recommend specific } \\
\text { investments }\end{array}$} & Amritsar & $3.95(0.56)$ & \multirow{4}{*}{$0.59(0.62)$} & \multirow{4}{*}{$\begin{array}{l}\text { No significant } \\
\text { difference } \\
\text { exists }\end{array}$} \\
\hline & & Jalandhar & $3.93(0.41)$ & & \\
\hline & & Ludhiana & $4.00(0.27)$ & & \\
\hline & & Mohali & $3.99(0.25)$ & & \\
\hline \multirow[t]{4}{*}{4} & \multirow{4}{*}{$\begin{array}{l}\text { Provide retirement } \\
\text { planning }\end{array}$} & Amritsar & $3.74(0.58)$ & \multirow{4}{*}{$6.42(0.00)^{*}$} & \multirow{4}{*}{$\begin{array}{l}\text { Significant } \\
\text { difference } \\
\text { exists }\end{array}$} \\
\hline & & Jalandhar & $3.45(0.67)$ & & \\
\hline & & Ludhiana & $3.59(0.54)$ & & \\
\hline & & Mohali & $3.36(0.58)$ & & \\
\hline
\end{tabular}




\begin{tabular}{|c|c|c|c|c|c|}
\hline \multirow[t]{4}{*}{5} & \multirow{4}{*}{$\begin{array}{l}\text { Provide general } \\
\text { financial planning }\end{array}$} & Amritsar & $3.77(0.65)$ & \multirow{4}{*}{$8.32(0.00)^{*}$} & \multirow{4}{*}{$\begin{array}{l}\text { Significant } \\
\text { difference } \\
\text { exists }\end{array}$} \\
\hline & & Jalandhar & $3.34(0.71)$ & & \\
\hline & & Ludhiana & $3.56(0.63)$ & & \\
\hline & & Mohali & $3.35(0.53)$ & & \\
\hline \multirow[t]{4}{*}{6} & \multirow{4}{*}{$\begin{array}{l}\text { Typically charge } \\
\text { commission on } \\
\text { purchases or trade that } \\
\text { the client makes }\end{array}$} & Amritsar & $3.95(0.44)$ & \multirow{4}{*}{$9.12(0.00)^{*}$} & \multirow{4}{*}{$\begin{array}{l}\text { Significant } \\
\text { difference } \\
\text { exists }\end{array}$} \\
\hline & & Jalandhar & $3.58(0.63)$ & & \\
\hline & & Ludhiana & $3.81(0.46)$ & & \\
\hline & & Mohali & $3.89(0.35)$ & & \\
\hline \multirow[t]{4}{*}{7} & \multirow{4}{*}{$\begin{array}{l}\text { Typically paid } \\
\text { commission based on } \\
\text { the amount of assets } \\
\text { that the client holds }\end{array}$} & Amritsar & $3.58(0.87)$ & \multirow{4}{*}{$\begin{array}{l}11.98 \\
(0.00)^{*}\end{array}$} & \multirow{4}{*}{$\begin{array}{l}\text { Significant } \\
\text { difference } \\
\text { exists }\end{array}$} \\
\hline & & Jalandhar & $3.29(0.87)$ & & \\
\hline & & Ludhiana & $3.32(0.93)$ & & \\
\hline & & Mohali & $2.76(0.96)$ & & \\
\hline \multirow[t]{4}{*}{8} & \multirow{4}{*}{$\begin{array}{l}\text { Required by law to act } \\
\text { in the client's best } \\
\text { interest }\end{array}$} & Amritsar & $3.26(0.87)$ & \multirow{4}{*}{$\begin{array}{l}18.69 \\
(0.00)^{*}\end{array}$} & \multirow{4}{*}{$\begin{array}{l}\text { Significant } \\
\text { difference } \\
\text { exists }\end{array}$} \\
\hline & & Jalandhar & $3.59(0.63)$ & & \\
\hline & & Ludhiana & $3.60(1.02)$ & & \\
\hline & & Mohali & $4.26(1.00)$ & & \\
\hline \multirow[t]{4}{*}{9} & \multirow{4}{*}{$\begin{array}{l}\text { Required by law to } \\
\text { disclose any conflict of } \\
\text { interests }\end{array}$} & Amritsar & $3.18(0.92)$ & \multirow{4}{*}{$\begin{array}{l}17.07 \\
(0.00)^{*}\end{array}$} & \multirow{4}{*}{$\begin{array}{l}\text { Significant } \\
\text { difference } \\
\text { exists }\end{array}$} \\
\hline & & Jalandhar & $3.46(0.71)$ & & \\
\hline & & Ludhiana & 3.34 (1.19) & & \\
\hline & & Mohali & $4.21(1.09)$ & & \\
\hline
\end{tabular}

*10 \% level of significance

**5\% level of significance

*** $1 \%$ level of significance

\section{RESEARCH FINDINGS}

It has been found that $57.6 \%$ of the retail equity investors have taken help of stockbrokers while investing in primary market and $97.9 \%$ of the respondents have taken the help of the stockbrokers while investing in secondary market. Moreover, it has also been found that $66.8 \%$ of the retail equity investors have been availing the services of stockbrokers for more than five years, $20.1 \%$ retail equity investors have been availing the services of stockbrokers for three to five years, $7.3 \%$ have been availing the services of stockbrokers for one to three years while $5.8 \%$ of retail equity investors have been availing the services of stockbrokers for less than one year and almost all the investors (98.8\%) have been aware of the fact that registration of the stockbrokers has been made compulsory.

It has been found that $97.6 \%$ of the retail equity investors have been aware of the guidelines laid down by SEBI for regulation of stockbrokers and $93.75 \%$ of the retail equity investors have stated that their stockbrokers often follow the guidelines laid down by SEBI.

It has been found from the study that $93 \%$ of the respondents have said that the failure of the stockbrokers to follow norms have not affected their investment decision and only $7 \%$ of the respondents have replied that it has affected their investment decision and they have changed their stockbroker.

It has been identified that a major chunk of respondents have rated all the stockbrokers services as always, often and occasionally availed by them.

\section{Implications of the Study}

This study would be of great use for investors and financial intermediaries who make decisions regarding investment. This study will help the investors and investment consultants in identifying profitable investment avenues. Investor's preference for equity will help the policymakers in formulating strategies and will also help the credit rating 
agencies in rating the investment instruments.

\section{Limitations and Future Research Directions}

Based on the study done by the researcher, the following suggestions are identified for further research.

1. Since the present study is at a state level, it could be extended to national level.

2. The impact of retail investment in capital market may be studied in view of rural investors.

3. The study may further be carried out to analyse the impact of reforms on the functioning of stock exchanges.

4. A study on the awareness of women investors about retail investment pattern could be attempted.

5. Implications of internet stock trading in India can be taken up for study.

6. Impact of technological innovation in capital markets can be studied.

\section{CONCLUSION}

Hence, it can be said that the time now is ripe for the stock market traders and also the investors, as many people have decided to go for the pie share. The stock brokers have seen an increase in the investment potential of the investors and there are many people who are entering the stock market trade and the last few years have seen an exponential increase in the people entering the stock broking trade. Hence in such a scenario, it is the duty of the stock broker to make the small investor aware of the situation to see to it that the small investor is not affected by such a withdrawal. In order to counter such a scenario, the current SEBI chief, Mr U $\mathrm{K}$ Sinha has urged the small investors and the middle class to invest more in the stock market as investing in the stock market and earning money in the stock exchange is not taboo anymore and the stock market as an investment option is still a very good option (Vyas and Joshi, 1995). It is estimated that even if a small percentage of the existing middle class invest in the stock market, the market will witness a surge of investment and may not require the investments made by the FDIs and the FIIs in the years to come (Hu \& Bentler, 1999). In order to make this a possibility, wherein the middle class people are encouraged to invest in the stock market, the stock broker and the small investor has to work hand in hand and the stock broker needs to give the correct advice to the investor so that he can get many more people to the stock market (Rajkumar, K.Prabhakar and Kavitha, N. Lakshmi, 2015). Moreover, it is explicit that the enactments like Companies Act 1956, Securities Contracts (Regulation) Act 1956 \& SEBI Act 1992 contain provisions to protect the interest of investors (Srinivasan, 2010).

\section{REFERENCES}

1) Chakrabarti, Rajesh (2004). Should You Bet on Your Broker's Advice - A Study of Analyst Recommendations in India. ICRA Bulletin Money Finance. April-June: 48-62.

2) Chakravarty, Ranjan R. (2010). Indian Equity Investors Survey- Detailed Report. <http://www.researchgate.net/publication/300 064492_India_Equity_Investor_Survey_Detailed_ Report>. Accessed 2014 July, 22.

3) Chi, Jauyui (2006). Sell or Hold? Influence on Investors' Decisions based on the availability of information sources and their Strength. $<\mathrm{ht} \mathrm{t} p$ : / / c i t e s e r e x. is t . psu.edu/viewdoc/download?doi=10\% \%320.923 0\&rep=rep1\&type >. Accessed 2012 March, 29.

4) Hirst, E., Koonce, L. and Simko, P. (1995). Investor Reactions to Financial Analysts' Research Reports. Journal of Accounting Research. 33(2): 335-351.

5) Hu, L. \& Bentler, P. M. (1999). Cut-off criteria for fit indexes in covariance structure analysis: Conventional criteria versus new alternatives. Structural Equation Modeling. 6(1): 1-55.

6) Hung, Angela A., Clancy, Norren and Dominitz, Jeff (2010). Investor Knowledge and Experience with Investment Advisers and Broker-dealers. In Olivia S. Mitchell and Annamaria Lusardi (ed.): 
Financial Literacy: Implications for Retirement Security and Financial Market place. Oxford University Press.

7) Imthiyas, Y., Shyamasundar, K. and Ramar, Sudha (2015). A Study on reach of Investment Awareness Programmes organized by EGovernance Services over Social Media. International Journal of Applied Environmental Sciences. 10(1): 65-69.

8) McAlexander, J. H. and Scammon, D. L. (1988). Are Disclosures Sufficient? A Micro Analysis of Impact in the Financial Services Market. Journal of Public Policy and Marketing. 7: 185-202.

9) Rajkumar, K. Prabhakar and Kavitha, N. Lakshmi (2015). Relevance of Stock Broking Industry in Capital Market with Special Reference to BSE, Mumbai. International Journal of Latest Technology in Engineering, Management and Applied Science. IV(X): 42-47.

10) Shukla, Rajeev K. and Upadhyaya, Ajit (2013). Determinants of Customers' Satisfaction for Stock Broking Services - An Empirical Analysis. Pacific Business Review International. 5(7): 74-83.

11) Srinivasan, G. and Mohan, K. (1995). Emerging Trends in Investment Management: The Indian Context. In S.J. Lalwani, (ed.): Security Market in India. Book Treasure, Jodhpur, India.

12) Srinivasan, R. (2010). Investor Services and Investor Protection. <http:// articlesbase.com / investingarticles / investor-servicesinvestorprotection-1658150. html>. Accessed 2011 June, 24.

13) U.S. Securities and Exchange Commission (2011). Study of the Staff of the U.S. Securities and Exchange Commission. <https://www.sec.gov/news/studies/2011/ 913 studyfinal.pdf $>$. Accessed 2013 March, 29.

14) V. Jeelan Basha (2014). An Empirical Study on Analysis of Stock Brokers in Indian Stock Markets with Special Reference Cash Market. Indian Journal of Applied Research 4(10): 140143.

15) Verma, K. K. and Tiwari, Prakash (2009). Analysis of Customers' Expectations towards Share Brokers: A Study. Pranjana. 12(1): 64-78.
16) Volpe, R., Kotel, J. and Chen, H. (2002). A Survey of Investment Literacy among Online Investors. Financial Counseling and Planning. 13(1): 1-13.

17) Vosra, Mefteh Rekik and Younes, Boujelbene (2013). Determinants of Individual Investors' Behaviour: Evidence from Tunisian Stock Market. IOSR Journal of Business and Management. 8(2): 109-119.

18) Vyas, V. S.and Joshi, A. K. (1995) Investment in Securities viz-a-viz Tax Exemptions: An Indian Perspective. In S.J. Lalwani, (ed.): Security Market in India. Book Treasure, Jodhpur, India. 